\title{
Controle op consumables door gebruik van IE-rechten en technologie
}

\author{
Mr.dr.A. Berlee*
}

\section{Inleiding}

Lenzen, toiletpapier, scheermesjes, inktcartridges en koffiecupjes zijn alle verbruiksgoederen, ook wel 'consumables' genoemd. Binnen deze groep verbruiksgoederen zijn twee categorieën te onderscheiden. Er zijn consumables die zelfstandig kunnen worden verbruikt, zoals de lenzen en toiletpapier. Daarnaast zijn er ook consumables waarvoor een 'durable' (hierna: verbruikend apparaat) nodig is, zoals de inktcartridges en koffiecupjes die respectievelijk een printer en een koffiezetapparaat nodig hebben om te kunnen worden verbruikt. ${ }^{1}$ Ik richt mij op deze laatste groep producten. Eerder dit jaar heeft de Hoge Raad namelijk een interessant arrest gewezen over de manier waarop controle kan worden uitgeoefend door de producent. Voor de producent is het economisch belang bij een verbruikend apparaat niet zozeer gelegen in de prijs die daarvoor wordt betaald, maar veeleer in de binding van de consument aan de consumables die door dat apparaat worden verbruikt. Zo is de verkoop van koffiecupjes voor Nespresso waarschijnlijk lucratiever dan de verkoop van koffiemachines voor dergelijke cupjes. Aan de hand van het genoemde arrest bespreek ik de verschillende juridische (on)mogelijkheden van de producent van het verbruikend apparaat om de controle over de markt van de consumables te krijgen en te houden.

De verschillende intellectuele-eigendomsrechten die de producent kan inzetten om dergelijke controle te verkrijgen, worden hierna op een rij gezet, waarna de juridische houdbaarheid van de handhaving daarvan wordt getoetst (par. 2). Maar we zien ook dat producenten technologische middelen kunnen inzetten bij de handhaving van hun rechten. In paragraaf 3 worden aan de hand van het praktische probleem van de handhaving van rechten de verschillende technologische oplossingen die hiervoor in aanmerking komen (kort) besproken. Er wordt afgesloten met een conclusie waarin aan de orde komt hoe de technologische middelen de focus lijken te verleggen van controle bij de concurrent naar de consument.

\section{Controle over consumables versie 1.0}

Wil de producent zijn positie op de markt van de consumables van zijn eigen verbruikend apparaat versterken, dan kan deze

\footnotetext{
Mr. dr. A. Berlee is universitair docent bij het Molengraaff Instituut voo Privaatrecht van de Universiteit Utrecht en redacteur van dit tijdschrift.

1. Bij scheermesjes hangt het er maar net van af of het heft en de kop één
} object zijn of twee losse onderdelen. daarvoor verschillende juridische instrumenten inzetten, in het bijzonder zijn intellectuele-eigendomsrechten (hierna ook: IE-rechten). Het kan hierbij gaan om:

1. octrooirechten verkregen ten aanzien van de verbruikende apparatuur, of op de innovaties in de (verpakking van de) consumables zelf;

2. het merkenrecht, met name om concurrenten aan te spreken die 'compatible met'-producten aanbieden;

3. het auteursrecht ten aanzien van de software op de verbruikende apparatuur.

In hoeverre de IE-rechten kunnen worden ingezet jegens de aanbieder van kloonproducten of de (consument)koper van het verbruikend apparaat, komt in deze paragraaf aan bod, waarbij ook mogelijke beperkingen voortvloeiende uit het overeenkomstenrecht de revue passeren.

\subsection{Octrooirecht en HP/Digital Revolution}

Het octrooirecht kan op twee manieren uitkomst bieden voor de producent. Ten eerste kan de huls waarin de consumable zit (bijvoorbeeld het cupje om de koffie, de cartridge om de printerinkt) zodanig innovatief zijn, dat daarvoor zelfstandige octrooirechtelijke bescherming kan worden verkregen. Wanneer het verbruikend apparaat op geen enkele andere manier kan worden gebruikt dan met de octrooirechtelijk beschermde consumable, is daarmee de markt voor concurrerende consumables gedurende de looptijd van het octrooi afgesloten. Een octrooi verkrijgen ten aanzien van de consumable is echter in de praktijk veelal niet mogelijk. ${ }^{2}$ Het ligt veeleer voor de hand dat de producent zich beroept op octrooirechtelijke bescherming die is verkregen ten aanzien van het verbruikend apparaat, bijvoorbeeld door de wisselwerking die de techniek mogelijk maakt tussen verbruikend apparaat en ingebrachte consumable.

Ter illustratie dient de casus in HP/Digital Revolution. ${ }^{3}$ HP - producent van printers en printercartridges - betichtte Digital Revolution ervan dat op haar website 123Inkt.nl enkele HP-compatibel printercartridges werden aangeboden die

2. 'Consumables zijn vaak wegwerpartikelen en de nieuwe inventieve wijzigingen ten opzichte van de stand van de techniek hebben niet altijd hun weerslag in de consumable.' Zie HR 19 april 2019, ECLI:NL:HR: 2019:650, IER 2019/21 m.nt. R. van Kleeff, BIE 2019/16 m.nt. H.J. Pot (HP/Digital Revolution) (n.d.).

3. HR 19 april 2019, ECLI:NL:HR:2019:650, IER 2019/21 m.nt. R. van Kleeff(HP/Digital Revolution). 
inbreuk maakten op de door HP geoctrooieerde uitvinding EP 2170617 (hierna: EP'617). Dit octrooi ziet onder andere op het opslaan van informatie over de cartridge en foutdetectiecodes. Digital Revolution betwistte echter met succes de nieuwheid en inventiviteit van sommige van de octrooiconclusies. ${ }^{4}$ Octrooiconclusies zijn de beschrijving van de uitvinding, die aan het slot van de octrooiaanvraag in één of meer conclusies een omschrijving geeft van datgene waarvoor het uitsluitend recht wordt verlangd. ${ }^{5}$ De omvang van het recht wordt bepaald door deze conclusies. ${ }^{6}$ De discussie aangaande de nieuwheid en inventiviteit van sommige van de conclusies laat ik voor wat ze is. ${ }^{7}$ Interessanter is in dit verband de vraag die aan de orde kwam, of er mogelijk sprake was van een indirecte inbreuk op octrooiconclusie 7 , waarover uitgebreid in paragraaf 2.2. Want wanneer er sprake is van een indirecte inbreuk kan de octrooihouder zijn exclusieve rechten voortvloeiende uit het octrooi uitoefenen jegens een derde, in dit geval Digital Revolution, en deze verbieden de concurrerende cartridges nog langer aan te bieden.

\subsection{Indirecte inbreuk op octrooirecht}

Het octrooirecht geeft de houder daarvan het exclusieve recht om onder andere het geoctrooieerde product in of voor zijn bedrijf te vervaardigen, te gebruiken, in het verkeer te brengen of verder te verkopen, te verhuren, af te leveren of anderszins te verhandelen, dan wel voor een of ander aan te bieden, in te voeren of in voorraad te hebben. ${ }^{8}$ In beginsel is dus toestemming van de octrooihouder vereist voor het gebruik van het geoctrooieerde voortbrengsel (zoals een printer). ${ }^{9}$ Is de gebruiker van de uitvinding niet gerechtigd tot gebruik van het geoctrooieerde dan kan de octrooihouder deze gebruiker aanspreken op (directe) inbreuk op het octrooirecht. Naast deze inbreuk kan ook indirect inbreuk worden gemaakt op het octrooirecht, namelijk door een derde.

Wanneer een derde middelen ${ }^{10}$ betreffende een wezenlijk bestanddeel van het geoctrooieerde aanbiedt of levert aan iemand die niet de toestemming heeft van de octrooihouder om het geoctrooieerde toe te passen in of voor zijn bedrijf, ${ }^{11}$ dan kan de octrooihouder deze derde aanspreken op grond van indirecte inbreuk op het octrooirecht, dit op grond van art. 73 Rijksoctrooiwet 1995 (ROW 1995).

4. De omvang van het octrooi wordt bepaald door de conclusies van het octrooischrift, zie art. 53 lid 1 jo. lid 2 ROW 1995.

5. Art. 24 lid 1 onder e ROW 1995.

6. Art. 53 lid 1 jo. lid 2 ROW 1995.

7. Zie daarvoor uitgebreid HR 19 april 2019, ECLI:NL:HR:2019:650, IER 2019/21 m.nt. R. van Kleeff, BIE 2019/16 m.nt. A. Tsoutsanis (HP/ Digital Revolution) (n.d.).

8. Art. 53 lid 1 onder a ROW 1995.

9. Uitzonderingen daargelaten, zie art. 55 e.v. ROW 1995.

10. Zoals grondstoffen, antistollingsmiddel aan slagers. Wellicht ook printercartridges, zie HR 19 april 2019, ECLI:NL:HR:2019:650, IER 2019/21 m.nt. R. van Kleeff (HP/Digital Revolution). Zie ook HR 3 november 2017, ECLI:NL:HR:2017:2807, NJ 2018/178 (MSD/Teva), r.o. 3.6.6.

11. Overigens is het mogelijk dat deze gebruiker desalniettemin rechtmatig gebruik makt van het geoctrooieerde, bijv. wanneer het een particulier betreft en het geoctrooieerde alleen in thuisgebruik wordt toegepast.

\section{Daarin staat te lezen:}

'De octrooihouder kan de vorderingen die hem ten dienste staan bij de handhaving van zijn octrooi instellen tegen iedere persoon, die in Nederland, Curaçao of Sint Maarten in of voor zijn bedrijf middelen betreffende een wezenlijk bestanddeel van de uitvinding aan anderen dan hen, die krachtens de artikelen 55 tot en met 60 [licentieverlening; $\mathrm{AB}$ ] tot toepassing van de geoctrooieerde uitvinding bevoegd zijn, aanbiedt of levert voor de toepassing van de geoctrooieerde uitvinding in Nederland, Curaçao of Sint Maarten, een en ander mits die persoon weet dan wel het gezien de omstandigheden duidelijk is, dat die middelen voor die toepassing geschikt en bestemd zijn.'

Toegepast op de casus in HP/Digital Revolution kwam het aan op de vraag of Digital Revolution (in)directe inbreuk op octrooiconclusie 7 had gemaakt door de printercartridges aan te bieden.

In conclusie 7 wordt - kort gezegd - een werkwijze van het overbrengen van gegevens tussen printer en cartridge beschreven door middel van onder andere software in de printer. ${ }^{12}$ Aangezien de daarbij behorende berekeningen plaatsvinden in de printer en niet in de printcartridge, kon er geen sprake zijn van directe inbreuk van Digital Revolution op deze octrooiconclusie. Het is namelijk de gebruiker van de printer, en niet de aanbieder van de printercartridges, die deze geoctrooieerde werkwijze toepast. Het ging in deze zaak niet om compatibele printers, maar printercartridges. HP gooide het daarom over de boeg van de indirecte inbreuk.

HP betoogde dat Digital Revolution indirect inbreuk zou hebben gepleegd op conclusie 7 , omdat zij de printercartridges aanbiedt of leverde aan gebruikers die geen licentie hebben verkregen van de octrooihouder (HP), om op deze manier de geoctrooieerde werkwijze toe te passen. Digital Revolution pleegt daarmee dus indirecte inbreuk. Digital Revolution bestreed dit met succes bij zowel het hof als de Hoge Raad.

Het Gerechtshof Den Haag kwam tot de conclusie dat HP de gebruiker wel degelijk een licentie heeft verschaft, namelijk een impliciete licentie bij de aankoop van een printer (cursivering toegevoegd; $\mathrm{AB}$ ).

'Digital Revolution heeft verder aangevoerd dat zij geen cartridges aanbiedt of levert aan "anderen dan hen, die krachtens de artikelen 55 tot en met 60 (dus krachtens licentie) tot toepassing van de geoctrooieerde uitvinding bevoegd zijn", zoals volgens artikel 73 ROW vereist voor het aannemen van indirecte inbreuk. $\mathrm{Zij}$ stelt daartoe dat de aanschaf van een HP printer van een type waarvoor de 123-cartridges geschikt en bestemd zijn, impliceert dat een

12. Octrooiconclusies kunnen zien op voortbrengselen (zoals een product of een machine) of op werkwijzen (een productieproces of een methode). In dit geval gaat het om een werkwijze om fouten te lokaliseren en schrijven. 
licentie wordt verkregen om die printer te gebruiken, met inbegrip van de door middel van de software van de controller van de printer daarin geïncorporeerde werkwijze volgens conclusie 7 van het octrooi. Dat verweer slaagt. Vast staat immers dat de printer alleen functioneert met een cartridge die is voorzien van een geheugeneenheid die in staat is met de software van de printer te communiceren zodanig dat de werkwijze van conclusie 7 kan worden toegepast. Miscommunicatie, bijvoorbeeld omdat de geheugeneenheid niet is ingericht voor toepassing van die werkwijze, leidt onherroepelijk tot het weigeren van de cartridge en dus tot disfunctioneren van het printersysteem, zoals HP ook nadrukkelijk heeft gesteld. Aangezien degene die een HP printer aanschaft mag verwachten dat de printer normaal moet kunnen functioneren, moet die toestemming - behoudens bij de aanschaf van de printer overeengekomen beperkende voorwaarden, die niet zijn gesteld of gebleken geacht worden zich tevens uit te strekken tot het gebruik van voor die printer geschikte cartridges die zelf geen inbreuk maken op enige productconclusie, zoals hiervoor is vastgesteld.'13

De Hoge Raad kwam tot dezelfde conclusie, maar langs een andere weg, namelijk door de generieke softwarelicentie die expliciet in de algemene voorwaarden voor het gebruik van de software in de printer was opgenomen, ${ }^{14}$ zodanig te interpreteren dat deze ook het gebruik op deze manier omvat (cursivering toegevoegd; $\mathrm{AB}$ ).

'3.5.4 Digital Revolution heeft in haar memorie van antwoord onder 14.3 gesteld dat HP door de verkoop en het in het verkeer brengen van een HP printer waarmee de werkwijze van conclusie 7 wordt toegepast, aan de verkrijger van die printer en diens rechtsopvolgers een licentie verleent voor het gebruik van de software van die printer, waarbij Digital Revolution heeft verwezen naar de algemene voorwaarden van HP (productie 26 bij akte van 7 juni 2016). HP heeft daartegen ingebracht dat de werkwijze volgens conclusie 7 zich met name afspeelt in de cartridge en dat de licentie zich niet uitstrekt tot inbreukmakende cartridges (mva inc. 83 en pleitnota 117).

3.5.5 Uit hetgeen het hof in de rov. 4.8 en 4.9 heeft overwogen (zie hiervoor in 3.3.5) volgt dat het hof de stelling van HP dat de werkwijze volgens conclusie 7 zich met name afspeelt in de cartridge, heeft verworpen. Daartegen komt HP in cassatie niet op. HP bestrijdt voorts niet dat de in haar algemene voorwaarden verleende licentie betrekking heeft op het gebruik van de software van de printer, die het mogelijk maakt te communiceren met cartridges die voldoen aan de kenmerken van conclusie 1 . Bij het uitgangspunt dat

13. Hof Den Haag 23 mei 2017, ECLI:NL:GHDHA:2017:1724, r.o. 4.36.

14. Deze bepaling is niet aangepast sinds de voorwaarden waarnaar wordt verwezen in de Hoge Raad-uitspraak, en zijn te vinden onder nr. 11 'Softwarelicenties' in de Algemene Voorwaarden van HP Nederland B.V. ten behoeve van online en telefonische verkopen, februari 2016. de cartridges van Digital Revolution geen inbreuk maken op - de immers vernietigde - conclusie 1 , geeft het oordeel van het hof dat Digital Revolution door het aanbieden of leveren van dergelijke cartridges evenmin indirect inbreuk maakt op conclusie 7 , geen blijk van een onjuiste rechtsopvatting, noch is dat oordeel onbegrijpelijk. Anders dan het onderdeel aanvoert, is van ontneming van eigendom geen sprake, nu het de software van de printer is die het gebruik van de cartridges van Digital Revolution mogelijk maakt en voor het gebruik van die software een licentie is verleend.'

De uitkomst is dezelfde: de koper van de printer verkrijgt een (impliciete) licentie voor het gebruik van de geoctrooieerde werkwijze, waardoor er dus geen sprake kon zijn van een indirecte inbreuk door Digital Revolution. ${ }^{15}$

\section{Niets vermelden over een softwarelicentie?}

Omdat de Hoge Raad, anders dan het hof, de impliciete licentie leest in de expliciete algemene softwarelicentie verleend in de algemene voorwaarden rijst de vraag: had HP er wellicht beter aan gedaan door in de verkoopvoorwaarden voor de printer dan helemaal niets te vermelden over een softwarelicentie? ${ }^{16}$ Dan had deze ook niet ruim geïnterpreteerd kunnen worden, en was een beroep op indirecte inbreuk wellicht wel geslaagd als aan de overige voorwaarden was voldaan.

Daarbij heeft het opnemen van een licentie om het gebruik van een geoctrooieerde werkwijze voorzien in software toe te staan ook niet zoveel zin voor een product dat enkel voor de consumentenmarkt geschikt is. ${ }^{17}$ De uitoefening van het exclusieve recht van de octrooihouder is namelijk beperkt tot het optreden tegen het onrechtmatige gebruik van het geoctrooieerde in of voor het bedrijf. Wat onder 'bedrijf valt wordt ruim geïnterpreteerd, ${ }^{18}$ maar niet zo ruim dat daaronder ook de thuisgebruiker valt. HP kan dus niet haar octrooi handhaven jegens de thuisgebruiker. Een licentie verlenen aan de thuisgebruiker is dus ook nutteloos en gelet op de formulering van de Hoge Raad lijkt dit mogelijk zelfs averechts te kunnen werken.

15. Daardoor was het ook niet nodig om toe te komen aan de vraag of printercartridges 'middelen betreffende een wezenlijk bestanddeel van de uitvinding' zijn in de zin van art. 73 ROW 1995. Zie voor de beoordeling van die vraag de criteria om na te lopen: HR 3 november 2017, ECLI:NL:HR:2017:2807 (MSD/Teva).

16. Zie ook over deze vraag L.E. Dijkman, Dutch Supreme Court Decides on Means-plus-Function Claims, Clarity and Implicit Licence in Printer Cartridge Patent Case, Journal of Intellectual Property Law \& Practice (14) 2019, afl. 10, p. 744, https://doi.org/10.1093/jiplp/jpz101, die terecht aangeeft in hoeverre dit een goede strategie is, gelet op de mogelijke auteursrechtelijke bescherming ten aanzien van de software als zodanig.

17. Koffiezetapparaten en printers die in de markt worden gezet voor consumenten worden ook gebruikt door (kleine) bedrijven; het is echter maar de vraag of je er dan goed aan doet als producent om te gaan handhaven jegens 'de kleine man'.

18. Verschuur, in: T\&C IE, art. 53 ROW 1995, nr. 2 onder b. 
Het leerstuk van de indirecte inbreuk uit hoofde van art. 73 ROW 1995 is namelijk niet een afgeleide van de directe inbreuk. ${ }^{19}$ Er kan dus sprake zijn van een indirecte inbreuk zonder dat er (eveneens) een directe inbreuk wordt gemaakt op het geoctrooieerde. Aangezien de Hoge Raad, anders dan het hof, zich lijkt te baseren op de expliciete licentie opgenomen in de algemene voorwaarden en niet op een impliciete licentie die het hof aanneemt, die zou zijn verleend bij de verkoop van de printer die gebruik maakt van de geoctrooieerde werkwijze, blijft de vraag dus open of een indirecte inbreuk wel zou kunnen worden aangenomen indien er helemaal niets over licentieverlening staat in de verkoopvoorwaarden, of dat de Hoge Raad ook in dat geval een impliciete licentieverlening zou hebben aangenomen. ${ }^{20}$

\section{Ofjuist een zeer beperkte licentie opnemen?}

Een andere optie is de mogelijkheid die in de uitspraak van het hof zijdelings werd genoemd, namelijk om in de licentieovereenkomst beperkingen op te leggen aan het gebruik van de printer. We zouden hierbij kunnen denken aan de voorwaarde dat alleen originele of geautoriseerde printercartridges zouden mogen worden gebruikt in de printer. Wat betreft de handhaving jegens de consumentenkoper weten we inmiddels dat deze voorwaarden niet op het octrooirecht kunnen worden gebaseerd, omdat het octrooi niet kan worden gehandhaafd jegens de thuisgebruiker.

Het verlenen van een licentie blijft dus in zoverre wel relevant voor de bedrijfsmatige gebruiker, tenminste, zo lijkt het. De vraag is in hoeverre dit juist is, gelet op de uitputtingsleer. ${ }^{21}$ Uitputting houdt namelijk in dat de octrooirechtelijke zeggenschap van de octrooihouder ten aanzien van het voortbrengsel (bijvoorbeeld de printer) is 'uitgeput' wanneer dat voortbrengsel eenmaal rechtmatig in het verkeer is gebracht. ${ }^{22}$ Rechtmatig in het verkeer brengen kan door de octrooihouder zelf zijn gedaan, of met diens toestemming. Bedrijfsmatig gebruiken, verhandelen of voor die doeleinden aanbieden,

19. Zoals het wel voor de invoering van art. $44 \mathrm{~A}$ Rijksoctrooiwet, thans art. 73 ROW 1995, was. Aangezien voor de invoering van het artikel de indirecte inbreuk op grond van onrechtmatige daad werd opgelost en vereiste dat de derde leverancier wetenschap had dat de afnemer met de geleverde middelen octrooi-inbreuk zal plegen. Zie HR 18 februari 1949, ECLI:NL:HR:1949:12, NJ 1949/357 m.nt. Ph.A.N. Houwing (Het Nederlands Beheersinstituut/Bonda). Hiervan is dus met art. 73 ROW 1995 afgestapt. Anders lijkt de suggestie van Verschuur in T\&C, waarin staat: 'De regeling van lid 1 houdt allereerst in dat de octrooihouder kan optreden tegen eenieder die aan de inbreukmaker middelen betreffende een wezenlijk bestanddeel van de uitvinding aanbiedt of levert voor toepassing daarvan.' Verschuur, in: T\&C IE, art. 73 ROW 1995, nr. 2.

20. Dit ligt overigens wel voor de hand als we kijken naar de jurisprudentie op dit punt in Duitsland en Engeland, zie daarvoor uitgebreider en met de nodige kanttekeningen gelet op specifieke Duitse wetgeving ten aanzien van uitputting de noot van Pot. HR 19 april 2019, ECLI:NL:HR:2019:650, BIE 2019/16 m.nt. H.J. Pot (HP/Digital Revolution).

21. Uitgebreid aan de orde, ook in rechtsvergelijkend perspectief door Pot in zijn noot bij het arrest. HR 19 april 2019, ECLI:NL:HR:2019:650, BIE 2019/16 m.nt. H.J. Pot (HP/Digital Revolution).

22. P.G.F.A. Geerts \& A.C.M. Alkema (red.), Kort begrip van het intellectuele eigendomsrecht, Deventer: Wolters Kluwer 2018, nr. 15. invoeren of in voorraad houden mag dus wanneer de printer eenmaal rechtmatig in het verkeer is gebracht. ${ }^{23}$ De octrooihouder heeft dan niet de mogelijkheid dit gebruik te verbieden. ${ }^{24}$ Dit ligt overigens iets ingewikkelder wanneer het octrooi enkel werkwijzeconclusies betreft. Die bijzondere situatie komt aan de orde in paragraaf 2.4.

Een octrooilicentie op grond van art. 55 t/m 60 ROW 1995 is dus niet nodig voor het gebruik van een printer die eenmaal rechtmatig in het verkeer is gebracht, ongeacht of het een thuisgebruiker betreft of iemand die gebruik makt van de printer in of voor zijn bedrijf. ${ }^{25}$ Dergelijke beperkingen zouden mogelijk wel jegens de gebruiker op grond van het 'gewone' overeenkomstenrecht kunnen gelden. ${ }^{26}$ Hierbij moet wel de kanttekening worden gemaakt dat wanneer beperkingen zijn opgenomen in algemene voorwaarden ze (mogelijk) niet kunnen worden afgedwongen door de leverancier, omdat deze mogelijk als onredelijk bezwarend worden aangemerkt, ${ }^{27}$ of in strijd zouden komen met de redelijke belangen van de (thuis)gebruiker en naar maatstaven van redelijkheid en billijkheid onaanvaardbaar worden geacht. ${ }^{28}$

Daarmee komen we tot een wat bijzondere vaststelling. Het opnemen van beperkingen ten aanzien van het gebruik van het verbruikend apparaat op grond van het octrooirecht dient in een dergelijk geval dus niet om het gebruik door de eerste

23. H. Struik, P.C. van Schelven \& W.A.J. Hoorneman, Softwarerecht: bescherming en gebruik van computerprogrammatuur onder auteursrecht en octrooirecht (Recht en Praktijk, nr. ICT2), Deventer: Kluwer 2010, sec. 2.VI.8.

24. Zie over verbodsacties, L.E. Dijkman, Het octrooirechtelijk verbod: heilig huisje in de storm?, Berichten Industriële Eigendom 2019, afl. 4, p. 186-192.

25. Anders: Van Kleeff, die verdedigt dat beperkingen ten aanzien van het gebruik van het geoctrooieerde met enkel geautoriseerde consumables ook de uitputting zou kunnen beperken tot dat specifieke gebruik. Niet uitgeput zijn dan, volgens hem, de mogelijkheden van de octrooihouder om op te treden tegen 'een ander gebruik (i.e. met niet-geautoriseerde cartridges)’. HR 19 april 2019, ECLI:NL:HR:2019:650, IER 2019/21 m.nt. R. van Kleeff (HP/Digital Revolution).

26. Waarbij schadevergoeding kan worden gevorderd in plaats van een verbodsactie.

27. Dit zou bijv. kunnen op grond van art. 6:237 onder b BW, hoewel deze bepaling van weinige praktische betekenis is naast art. 7:17 $\mathrm{BW}$, zie B. Wessels, R.H.C. Jongeneel \& M.L. Hendrikse (red.), Algemene voorwaarden (Recht en Praktijk, nr. CA1), Deventer: Kluwer 2010, 12.3 'Eigen verplichtingen wezenlijk beperken', en ook is er weinig houvast te vinden in de rechtspraak. Het lijkt me niet direct voor de hand liggen dat een verbruikend apparaat dat een ongeautoriseerde consumable weigert, of een apparaat dat in zijn geheel niet meer werkt nadat gebruik is gemaakt (geprobeerd te maken) van een ongeautoriseerde consumable als non-conform kan worden aangemerkt. Het geleverde beantwoordt immers aan de overeenkomst (geschikt voor geautoriseerde cartridges), en wanneer de printer niet meer functioneert door gebruik van een ongeautoriseerde cartridge komt dan voor rekening van de koper/gebruiker, niet de verkoper.

28. Op grond van art. 6:2 lid 2 en 6:248 lid 2 BW. Zie voor een soortgelijke redenering betreffende auteursrechtelijke beperkingen waaraan geen auteursrechtelijke werking toekomt, T.F.E. Tjong Tjin Tai, De omvang van het gebruiksrecht van programmatuur, Computerrecht 2001, afl. 2, p. 60-65. 
(veelal consument)koper daadwerkelijk te beperken, ${ }^{29}$ maar om een derde ervan te weerhouden om concurrerende consumables te kunnen leveren.

\subsection{Dit product is compatibel met...}

Een printercartridge verkoopt natuurlijk alleen als deze ook daadwerkelijk kan worden gebruikt in de printer, en wanneer de koper weet dat deze het zal doen in zijn printer. Om dit duidelijk te maken aan de consument is het daarom van belang dat de aanbieder van dergelijke kloonproducten ook de compatibiliteit met het verbruikende apparaat kan adverteren. Dat kan door zowel de originele als de geautoriseerde consumable aan te bieden en daaronder direct een compatibel 'huismerk', zoals 123inkt.nl doet. Ook mogelijk is dat voor het adverteren de merknaam van het verbruikend apparaat wordt gebruikt. Denk aan Koffiecupster, die op haar website koffiecapsules 'voor Nespresso' ${ }^{\circ}$ aanbiedt. ${ }^{30}$ De vraag of de producent kan optreden tegen het gebruik van zijn merknaam door een concurrent om de compatibiliteit van de concurrerende consumable aan te geven, moet worden beantwoord aan de hand van het merkenrecht en de vereisten van vergelijkende reclame. ${ }^{31}$

\section{... het merkenrecht}

Wanneer een merk is ingeschreven, geeft het merk de houder daar een uitsluitend recht op. ${ }^{32}$ Het is dus in beginsel aan de houder van het merk om toestemming voor het gebruik van het merk te verlenen. ${ }^{33}$ Dit zou betekenen dat bijvoorbeeld de houder van het merk Nespresso, zijnde Nestlé, ${ }^{34}$ Koffiecupster.nl zou kunnen verbieden gebruik te maken van de aanduiding 'voor Nespresso ${ }^{\infty}$ op haar website als Nespresso daarvoor geen toestemming heeft verleend, ware het niet dat een derde niet kan worden verboden om gebruik te maken van het merk ter identificatie of verwijzing naar waren of diensten wanneer dit noodzakelijk is om de bestemming van een waar of dienst aan te duiden. ${ }^{35}$

29. Immers, wanneer de printer is doorverkocht op de tweedehandsmarkt, neem ik aan dat daarbij niet eveneens contractsoverneming met betrekking tot de licentie zal plaatsvinden. Zie ook HR 19 april 2019, ECLI:NL:HR:2019:650, BIE 2019/16 m.nt. H.J. Pot (HP/Digital Revolution).

30. Daarnaast kan men ook denken aan het gebruik van foto's die mogelijk auteursrechtelijk beschermd zijn. Dit kan relatief gemakkelijk worden vermeden door zelf promotiemateriaal te maken.

31. In alle gevallen wordt uitgegaan van daadwerkelijke compatibiliteit. Als blijkt dat de concurrerende consumable niet daadwerkelijk 'werkt' met het verbruikend apparaat, dan kan de koopovereenkomst van de consumables op basis van dwaling worden vernietigd ex art. 6:228 lid 1 onder a BW.

32. Art. 2.20 lid 1 Benelux-verdrag inzake de intellectuele eigendom (BVIE).

33. Zie art. 2.20 lid 2 en 3 BVIE.

34. Specifieker: Société des Produits Nestlé S.A. op grond van registratienummer 0153246, zie www.boip.int/en/trademarks-register.

35. Art. 2.23 lid 1 onder c BVIE.
Dit geldt met name als accessoire of onderdeel, ${ }^{36}$ en alleen voor zover dergelijk gebruik eerlijk is. ${ }^{37}$ In Gillette/LA-Laboratories heeft het Hof van Justitie van de Europese Unie (hierna: $\mathrm{HvJ} E U)^{38}$ uitgelegd wat er moet worden verstaan onder 'noodzakelijk gebruik'. ${ }^{9}$

In die zaak ging het om LA-Laboratories, die onder de naam Parason Flexor handelde in scheermesjes en heften en op de verpakking van haar producten een etiket aanbracht met de tekst: 'alle heften van Parason Flexor en van Gillette Sensor zijn compatibel met dit mesje'. LA-Laboratories had geen merklicentie of enige andere toestemming van Gillette Company verkregen, de houder van het merkenrecht. ${ }^{40}$ Gillette Company stelde daarom dat LA-Laboratories inbreuk maakte op haar merk. LA-Laboratories deed echter een beroep op de hierboven aangehaalde beperking op het merkrecht, namelijk dat de verwijzing nodig was om de bestemming van de waar aan te duiden.

Het Hof van Justitie plaatste deze beperking op het merkrecht in het licht van het vrije verkeer van goederen en diensten en de belangrijke rol van het merkenrecht in de mededinging. ${ }^{41}$ Dit houdt onder andere in dat de merkhouder soms moet accepteren dat zijn merk wordt gebruikt door een derde om 'het publiek begrijpelijke en volledige informatie te verstrekken over de bestemming van het product dat hij in de handel brengt, met name over de compatibiliteit van dit product met het van die merken voorziene product'. ${ }^{42}$ Dergelijk gebruik hoeft alleen te worden toegestaan indien dit in de praktijk 'het

36. Dit zijn voorbeeldcategorieën, 'de bestemming van de producten als accessoire of onderdeel [wordt] slechts als voorbeeld [...] gegeven, aangezien het wellicht gaat om gangbare situaties waarin het nodig is gebruik te maken van een merk om de bestemming van een product aan te geven, (...) zodat de toepassing (...) niet is beperkt tot deze situaties'. HvJ EG 17 maart 2005, C-228/03, ECLI:EU:C:2005:177 (Gillette/LA-Laboratories), par. 32 .

37. Art. 2.23 lid 1 aanhef en onder c BVIE.

38. Destijds Hof van Justitie van de Europese Gemeenschappen. HvJ EG 17 maart 2005, ECLI:EU:C:2005:177, IER 2005/51 m.nt. H.M.H. Speyart (Gillette/LA-Laboratories).

39. Eigenlijk ging het in Gillette/LA-Laboratories om 'wanneer dat nodig is' en niet 'wat noodzakelijk is', op grond waarvan in een zaak voor het Hof Den Haag in april 2019 is betoogd dat daarmee een koerswijziging van de Europese wetgever is bedoeld ten opzichte van het geldend recht ten tijde van het arrest Gillette/LA-Laboratories, en dat daarmee dat arrest niet meer geldend zou zijn. Dit betoog werd verworpen door het hof. In punt 40: '(...) Daarmee wordt hetzelfde bedoeld. Dat hier het woord "noodzakelijk" wordt gebruikt in plaats van het woord "nodig" duidt ook niet op een koerswijziging van de Europese wetgever en brengt dus ook niet mee dat het arrest Gillette/LA Laboratories geen geldend recht meer is. In de Franse en Engelse tekstversie is de bepaling in dit opzicht niet veranderd ("nécessaire" respectievelijk "necessary").' Zie Hof Den Haag 30 april 2019, ECLI:NL:GHDHA:2019:897 (NXP/Infineon).

40. HvJ EG 17 maart 2005, C-228/03, ECLI:EU:C:2005:177 (Gillette/LALaboratories), par. 14-15.

41. HvJ EG 17 maart 2005, C-228/03, ECLI:EU:C:2005:177, IER 2005/51 m.nt. H.M.H. Speyart (Gillette/LA-Laboratories), par. 29. Zie ook HvJ EG 23 februari 1999, C-63/97, ECLI:EU:C:1999:82 (BMW), par. 62 en HvJ EG 7 januari 2004, C-100/02, ECLI:EU:C:2004:11 (Gerolsteiner Brunnen).

42. HvJ EG 17 maart 2005, C-228/03, ECLI:EU:C:2005:177, IER 2005/51 m.nt. H.M.H. Speyart (Gillette/LA-Laboratories), par. 34. 


\section{Maandblad}

enige middel' is om dergelijke informatie mee te delen. ${ }^{43}$ Is er bijvoorbeeld een technische standaard waarnaar kan worden verwezen - die bekend is bij het publiek - in plaats van het merk gebruiken, dan is verwijzen niet het 'enige middel' en levert het gebruik van het merkrecht een inbreuk op. ${ }^{44}$

Van inbreuk kan eveneens sprake zijn indien de verwijzing weliswaar noodzakelijk is, maar niet 'eerlijk'. ${ }^{45}$ Ook dit is nader uitgewerkt door het Hof van Justitie in de Gillette/LALaboratories-zaak. Zo is bijvoorbeeld het gebruik van het merk niet eerlijk wanneer daardoor de indruk kan ontstaan dat er een commerciële band tussen de derde en de merkhouder bestaat, ${ }^{46}$ wanneer de waarde van het merk wordt aangetast doordat ongerechtvaardigd voordeel wordt getrokken uit het onderscheidend vermogen of de reputatie ervan, ${ }^{47}$ wanneer de goede naam van dit merk wordt geschaad of kleinerende uitlatingen erover worden gedaan, ${ }^{48}$ of wanneer de derde zijn product voorstelt als een imitatie of namaak van het product, voorzien van het merk waarvan hij niet de houder is. ${ }^{49}$ Kortom, wanneer de concurrent voor de compatibiliteit van zijn concurrerende consumable niet anders kan dan verwijzen naar het merk van het product waarmee het compatibel is, ${ }^{50}$ en dit op een eerlijke manier doet, is een dergelijke verwijzing in beginsel ook toegestaan.

Wanneer het merk tevens wordt gebruikt om reclame te maken voor een concurrerende consumable, moet ook worden gekeken naar de voorwaarden te vinden in Boek 6 Burgerlijk Wetboek (BW) voor het maken van dit soort vergelijkende reclame.

43. HvJ EG 17 maart 2005, C-228/03, ECLI:EU:C:2005:177, IER 2005/51 m.nt. H.M.H. Speyart (Gillette/LA-Laboratories), par. 35.

44. Zoals bijv. codes op autobanden die aan potentiële kopers aangeven welke banden voor de auto bedoeld zijn. Zie ook conclusie van A-G Tizzanopara bij HvJ EG 9 december 2004, C-228/03, ECLI:EU:C:2004:786 (Gillette/LA-Laboratories), par. 47.

45. Hiervoor verwijst het HvJ naar de vaste rechtspraak betreffende eerlijk gebruik, zie HvJ EG 17 maart 2005, C-228/03, ECLI:EU:C:2005:177, IER 2005/51 m.nt. H.M.H. Speyart (Gillette/LA-Laboratories), par. 41; HvJ EG 23 februari 1999, C-63/97, ECLI:EU:C:1999:82, NJ 2001/134 m.nt. J.H. Spoor, IER 1999/16 m.nt. RdR (BMW/Deenink), par. 61; HvJ EG 7 januari 2004, C-100/02, ECLI:EU:C:2004:11, IER 2004/29 m.nt. JK, par. 24.

46. HvJ EG 23 februari 1999, C-63/97, ECLI:EU:C:1999:82, NJ 2001/134 m.nt. J.H. Spoor, IER 1999/16 m.nt. RdR (BMW/Deenink), par. 51; HvJ EG 17 maart 2005, C-228/03, ECLI:EU:C:2005:177, IER 2005/51 m.nt. H.M.H. Speyart (Gillette/LA-Laboratories), par. 42.

47. HvJ EG 23 februari 1999, C-63/97, ECLI:EU:C:1999:82, NJ 2001/134 m.nt. J.H. Spoor, IER 1999/16 m.nt. RdR (BMW/Deenink), par. 52; HvJ EG 17 maart 2005, C-228/03, ECLI:EU:C:2005:177, IER 2005/51 m.nt. H.M.H. Speyart (Gillette/LA-Laboratories), par. 43.

48. HvJ EG 17 maart 2005, C-228/03, ECLI:EU:C:2005:177, IER 2005/51 m.nt. H.M.H. Speyart (Gillette/LA-Laboratories), par. 44.

49. HvJ EG 17 maart 2005, C-228/03, ECLI:EU:C:2005:177, IER 2005/51 m.nt. H.M.H. Speyart (Gillette/LA-Laboratories), par. 45. Zie voor het overzicht par. 49.

50. De aanduiding moet dus ook juist zijn. Als de aanduiding te generiek is en stelt 'compatible' te zijn, en dit niet is voor alle producten die onder die aanduiding vallen, gaat het feest alsnog niet door, zie Hof Den Haag 30 april 2019, ECLI:NL:GHDHA:2019:897, r.o. 41 e.v.

\section{... de voorwaarden voor vergelijkende reclame}

Wanneer reclame wordt gemaakt 'waarbij een concurrent dan wel door een concurrent aangeboden goederen of diensten uitdrukkelijk of impliciet worden genoemd', spreekt men ook wel van vergelijkende reclame, op grond van art. 6:194a lid 1 BW. ${ }^{51}$ Hier is al snel sprake van, ${ }^{52}$ en zal dus ook iedere reclame betekenen van aanbieders van kloonproducten die verwijzen naar de compatibiliteit met producten van de concurrent. Zo heeft het HvJ EU bepaald dat van vergelijkende reclame al sprake kan zijn indien wordt verwezen in de reclame naar de (OEM-)artikelnummers van de concurrent. ${ }^{53}$ Onder vergelijkende reclame moet eveneens worden verstaan die reclame die enkel herkenbaar refereert aan een product of dienst van een concurrent, en deze hoeft dus niet altijd een daadwerkelijke vergelijking van twee producten te maken. ${ }^{54}$ Hier was bijvoorbeeld ook sprake van in de hierboven genoemde zaak Gillette/LA-Laboratories, waarin de mededeling van de compatibiliteit van het kloonproduct met het origineel verbruikend apparaat centraal stond, ${ }^{55}$ en bij het verwijzen naar 'voor Nespresso ${ }^{\oplus}$ door Koffiecupster.nl.

Vergelijkende reclame maken is alleen geoorloofd indien is voldaan aan de cumulatieve voorwaarden zoals opgesomd in

51. Ingevoerd ter implementatie van Richtlijn 97/55/EG van het Europees Parlement en de Raad van 6 oktober 1997 tot wijziging van Richtlijn 84/450/EEG inzake misleidende reclame teneinde ook vergelijkende reclame te regelen en laatstelijk aangepast op grond van de implementatie van Richtlijn 2006/114/EG van het Europees Parlement en de Raad van 12 december 2006 inzake misleidende reclame en vergelijkende reclame, PbEG 2006, L 376, p. 21-27.

52. Zie GS Onrechtmatige daad, art. 6:194a BW, aant. 3.1.

53. Destijds nog Hof van Justitie van de Europese Gemeenschappen. HvJ EG 25 oktober 2001, ECLI:EU:C:2001:566, NJ 2002/142 m.nt. D.W.F. Verkade (Toshiba/Katun). Zo concludeerde het Hof dat: '1) (...) als vergelijkende reclame die objectief een of meer wezenlijke, relevante, controleerbare en representatieve kenmerken van goederen met elkaar vergelijkt, kan worden aangemerkt, de vermelding in de catalogus van een verkoper van reserveonderdelen en verbruiksartikelen die geschikt zijn voor de producten van een fabrikant van apparaten, van de artikelnummers (OEM-artikelnummers) waarmee laatstgenoemde zijn eigen reserveonderdelen en verbruiksartikelen aanduidt.'

54. D.W.F. Verkade, Misleidende (B2B) reclame en vergelijkende reclame (Mon. BW, nr. B49b), Deventer: Kluwer 2011/3.90; GS Onrechtmatige daad, art. 6:194a BW, aant. 6.

55. Ook al kwam het Hof hier - jammer genoeg volgens Speyart - niet op terug in het betoog, zie HvJ EG 17 maart 2005, C-228/03, ECLI:EU:C: 2005:177, IER 2005/51 m.nt. H.M.H. Speyart (Gillette/LA-Laboratories). 
art. 6:194a lid $2 \mathrm{BW} .^{56} \mathrm{Bij}$ de uitleg van deze gestelde eisen prevaleert de meest gunstige uitleg voor deze reclame. ${ }^{57}$ Ook dit is te verklaren uit hoofde van het willen bevorderen van concurrentie. ${ }^{58}$ De vergelijking met de voorwaarden voor 'eerlijk gebruik' van het merk, zoals hierboven al uiteen is gezet, ${ }^{59}$ is dan ook gauw gemaakt, en deze voorwaarden komen overeen met de gestelde eisen voor vergelijkende reclame in art. 6:194a lid 2 BW.

Kortom, het lijkt er niet op dat er kan worden opgetreden tegen reclame die simpelweg stelt dat het product dat wordt aangeboden 'compatibel is met [het verbruikend apparaat van de concurrent]'.

\subsection{Van derde naar gebruiker}

Tot dusver hebben we vooral gekeken naar de mogelijkheden die de producent ter beschikking staan om controle over de markt van consumables te behouden door zijn pijlen direct op een concurrent te richten. Het is echter ook mogelijk om controle te houden bij de gebruiker van het verbruikende apparaat (de printer, het koffiezetapparaat enzovoort). We hebben eerder al de mogelijkheden om beperkingen op te leggen aan het gebruik van het verbruikende apparaat via het overeenkomstenrecht bekeken, met dien verstande dat de opgelegde gebruiksverplichtingen niet zodanig mogen zijn dat ze onredelijk bezwarend worden vermoed, of naar maatstaven van redelijkheid en billijkheid onaanvaardbaar zijn. ${ }^{60}$ Daarnaast zijn er

56. De voorwaarden zijn aldus dat de vergelijkende reclame niet: (a) misleidend is of een misleidende handelspraktijk betreft; (b) goederen of diensten vergelijkt die in dezelfde behoeften voorzien of voor hetzelfde doel zijn bestemd; (c) op objectieve wijze een of meer wezenlijke, relevante, controleerbare en representatieve kenmerken van deze goederen en diensten, zoals de prijs, met elkaar vergelijkt; (d) er niet toe leidt dat op de markt de adverteerder wordt verward met een concurrent, of de merken, handelsnamen, andere onderscheidende kenmerken, goederen of diensten van de adverteerder met die van een concurrent; (e) niet de goede naam schaadt van of zich niet kleinerend uitlaat over de merken, handelsnamen, andere onderscheidende kenmerken, goederen, diensten, activiteiten of omstandigheden van een concurrent; ( $f$ ) voor producten met een benaming van oorsprong in elk geval betrekking heeft op producten met dezelfde benaming; (g) geen oneerlijk voordeel oplevert ten gevolge van de bekendheid van een merk, handelsnaam of andere onderscheidende kenmerken van een concurrent dan wel van de oorsprongsbenamingen van concurrerende producten; en (h) niet goederen of diensten voorstelt als een imitatie of namaak van goederen of diensten met een beschermd merk of beschermde handelsnaam.

57. HvJ EG 25 oktober 2001, ECLI:EU:C:2001:566, NJ 2002/142 m.nt. D.W.F. Verkade, IER 2002/8, m.nt. J.J.C. Kabel (Toshiba/Katun), par. 37.

58. Zo resumeerde het Hof het als volgt: 'Onder deze omstandigheden moet rekening worden gehouden met de doelstellingen van de gewijzigde richtlijn 84/450. In dit verband blijkt uit de tweede overweging van de considerans van richtlijn $97 / 55$ dat vergelijkende reclame ertoe zal bijdragen dat de voordelen van de verschillende vergelijkbare producten objectief worden belicht, en dat zij aldus in het belang van de consument een stimulans zal vormen voor de concurrentie tussen de leveranciers van goederen en diensten.'

59. Zie ook Geerts \& Verschuur 2018/395 en Speyart in zijn laatste alinea in de noot bij het arrest, HvJ EG 17 maart 2005, C-228/03, ECLI:EU:C: 2005:177, IER 2005/51 m.nt. H.M.H. Speyart (Gillette/LA-Laboratories).

60. Zie par. 2.2 mogelijk nog andere mogelijkheden om een zekere mate van controle over de markt van consumables uit te oefenen. Deze vloeien voornamelijk voort uit de juridische bescherming van software in het verbruikend apparaat.

\section{Nog niet uitgeput van het octrooirecht?}

Nog één keer terug naar HP/Digital Revolution en de omstandigheden van dat geval. Uiteindelijk draaide het om de vraag of Digital Revolution indirect inbreuk maakte op octrooiconclusie 7 . In conclusie 7 wordt - kort gezegd - een werkwijze van het overbrengen van gegevens tussen printer en cartridge beschreven door middel van onder andere software in de printer. Deze werkwijzeconclusie werd niet vernietigd en bleef in stand. We weten inmiddels dat de gebruiker om meerdere redenen de leverancier van het verbruikend apparaat niet hoeft te vrezen:

1. Thuisgebruikers hoeven de octrooihouder nimmer te vrezen, aangezien het octrooi alleen kan worden gehandhaafd jegens degene die zonder toestemming het octrooi toepast in of voor zijn bedrijf.

2. Indien er een (generieke) softwarelicentie is opgenomen in de algemene voorwaarden, zonder beperkingen, wordt daaruit ook een impliciete licentie afgeleid, strekkende tot het gebruik van software in het verbruikend apparaat door (werkende maar niet-geautoriseerde) consumables.

3. De octrooiconclusies zijn uitgeput.

Dit laatste ligt echter iets gecompliceerder. In HP/Digital Revolution werden octrooiconclusies $1 \mathrm{t} / \mathrm{m} 6$ vernietigd. Deze vernietiging had als gevolg dat EP'617 enkel nog geldige werkwijzeconclusies betrof. Dit is relevant omdat het in Nederland geen uitgemaakte zaak is dat de octrooirechtelijke uitputtingsleer ook van toepassing is op (louter) werkwijzeconclusies. ${ }^{61}$ In het bijzonder ingewikkeld is de situatie wanneer de werkwijze is vervat in software. ${ }^{62}$ Strikt genomen ziet art. 53 lid 5 ROW 1995, waarin de octrooirechtelijke uitputtingsregel is vervat, namelijk alleen op voortbrengselen, en niet op werkwijzen.

Met Pot ben ik het eens dat wanneer een product zelf geoctrooieerd is, of het een rechtstreeks verkregen voortbrengsel van een geoctrooieerde werkwijze is, niet alleen de productconclusies zouden moeten zijn uitgeput op grond van art. 53 lid 5 ROW 1995, maar eveneens de werkwijzeconclusies. ${ }^{63}$ Is dit anders, dan zou de octrooihouder die een nieuw en inventief product heeft uitgevonden met het toevoegen van een (weinig tot niet-)inventieve werkwijzeconclusie 'de uitputtingsregel effectief kunnen omzeilen. Dat is niet redelijk en in strijd met de ratio van het uitputtingsleerstuk: de octrooihouder die een product op de markt brengt heeft wat dat product

61. HR 19 april 2019, ECLI:NL:HR:2019:650, BIE 2019/16 m.nt. H.J. Pot (HP/Digital Revolution); Struik, Schelven \& Hoorneman 2010, sec. 2.VI.7.

62. R.B. Bakels, Sofware: werkwijze of voortbrengsel?, Bijblad Industriële Eigendom 2003, p. 431.

63. HR 19 april 2019, ECLI:NL:HR:2019:650, BIE 2019/16 m.nt. H.J. Pot (HP/Digital Revolution). 
betreft zijn winst behaald en zou geen verdere rechten moeten kunnen doen gelden. ${ }^{64}$

Het probleem in de casus van HP/Digital Revolution was nu juist dat het octrooi EP'617 na vernietiging van conclusies $1 \mathrm{t} / \mathrm{m} 6$ enkel nog werkwijzeconclusies omvatte. Indien HP verder geen octrooien heeft ten aanzien van de printers die gebruik maken van deze werkwijze, is de vraag of de geoctrooieerde zeggenschap is uitgeput dus niet direct gemakkelijk te beantwoorden. Indien er geen uitputting optreedt, behoudt de octrooihouder dus zijn zeggenschap en kan hij ten aanzien van het bedrijfsmatig gebruik van de printer voorwaarden aan dat gebruik op grond van zijn octrooi stellen.

\section{Embedded software en de auteursrechtelijke bescherming}

De software in het verbruikend apparaat - ook wel embedded software genoemd - kan ook auteursrechtelijk beschermd zijn. ${ }^{65}$ De auteursrechthebbende heeft in dat geval ook enkele mogelijkheden tot zijn beschikking om controle op het gebruik van het werk uit te oefenen. Ten aanzien van het gebruik zijn de mogelijkheden wel beperkt.

De rechten van de auteursrechthebbenden zien namelijk op de exploitatie van het werk ${ }^{66}$ en vinden we in art. 1 Auteurswet (Aw). ${ }^{67}$ Het gaat daarbij om het (behoudens wettelijke beperkingen) exclusieve recht tot het openbaar maken van het werk en het verveelvoudigen van het werk, waaronder ook wordt verstaan het veranderen van het programma, bijvoorbeeld door vertalen of bewerken, ${ }^{68}$ en elke vorm van distributie, met inbegrip van het verhuren van een oorspronkelijk computerprogramma of kopieën daarvan onder het publiek. ${ }^{69}$ Een handeling die valt onder een van deze exclusieve rechten mag dus in beginsel alleen met toestemming van de auteursrechthebbende. Mogelijke strijd met een van deze rechten in het kader van het enkele gebruik van embedded software, zoals die aanwezig is in verbruikende apparatuur, is niet gauw aan de orde. $^{70}$

64. HR 19 april 2019, ECLI:NL:HR:2019:650, BIE 2019/16 m.nt. H.J. Pot (HP/Digital Revolution).

65. Computerprogramma's worden geclassificeerd als werken van letterkunde, wetenschap of kunst op grond van art. 10 lid 1 onder $12 \mathrm{Aw}$. Zie voorts de Softwarerichtlijn alsmede de bijzondere bepalingen omtrent computerprogramma's in art. 45h- 45n Aw. Uitgebreid: Struik, Schelven \& Hoorneman 2010. Zie ook overweging 7 Softwarerichtlijn: 'Voor de toepassing van deze richtlijn moet de term "computerprogramma" alle programma's in gelijk welke vorm omvatten, met inbegrip van programma's die in de apparatuur zijn ingebouwd.'

66. En dus niet zozeer de consumptie (gebruik of genot) van dat werk. Zie D.J.G. Visser, Auteursrecht op toegang, diss. Leiden, Den Haag: VUGA 1997, p. 26 e.v.

67. Zie ook art. 4 lid 1 Richtlijn 2009/24/EG van het Europees Parlement en de Raad van 23 april 2009 betreffende de rechtsbescherming van computerprogramma's ('Softwarerichtlijn'), PbEG 2009, L 111, p. 16-22.

68. Art. 13 Aw en art. 4 lid 1 onder b Softwarerichtlijn.

69. Art. 4 lid 1 onder c Softwarerichtlijn.

70. Dit wordt anders wanneer het verbruikend apparaat mogelijk defect is en je de software zou willen 'repareren'. Zie over de mogelijke juridische haken en ogen daarvan A. Berlee, Op afstand bestuurbaar eigendom, $\mathrm{MvV} 2018$, afl. $7 / 8$, p. 255-261, https://doi.org/10.5553/MvV/ 157457672018016708006 .
Van Kleeff opperde in zijn noot bij het HP/Digital Revolution-arrest dat desalniettemin via een licentieovereenkomst beperkingen aan het gebruik van de printer kunnen worden gesteld op grond van de auteursrechtelijke bescherming van de software in het verbruikend apparaat. ${ }^{71}$ Deze zou dan kunnen inhouden dat alleen geautoriseerde of originele printercartridges mogen worden gebruikt. Onduidelijk is welke van de exploitatierechten van de auteursrechthebbende een dergelijke beperking op basis van het auteursrecht zou kunnen rechtvaardigen. Daarom denk ik dat dergelijke beperkingen van het gebruik alleen verbintenisrechtelijke werking hebben. Laten we voor het vervolg aannemen dat dit wél zou kunnen op basis van het auteursrecht, de vraag is dan of deze beperkingen kunnen worden afgedwongen of dat ook hier de uitputtingsleer roet in het eten gooit.

Het auteursrecht kent namelijk net als het merken- en octrooirecht de uitputtingsleer, die de mogelijkheid van de rechthebbende beperkt tot het controleren van eenmaal rechtmatig in verkeer gebrachte kopieën van het werk. Deze regeling is vervat in art. $12 \mathrm{~b}$ Aw en bepaalt dat na de eerste verkoop van een kopie van het programma door de rechthebbende of met diens toestemming het recht om controle uit te oefenen op de distributie van die kopie komt te vervallen, met uitzondering van de verdere verhuur van het programma.

Enkel het distributierecht wordt dus uitgeput na eerste verkoop van de kopie. De theoretische onderbouwing van de uitputtingsleer van het distributierecht in het auteursrecht is in wezen niet anders dan die van de uitputtingsleer in het merkenrecht en octrooirecht. $\mathrm{Zij}$ is gestoeld op het idee dat hiermee:

1. de ruimte wordt geboden aan de vrije verhandeling van in het verkeer zijnde kopieën van het werk (verkeerstheorie);

2. het auteursrecht in de pas loopt met de vrijheid die de eigenaar van het fysieke exemplaar geniet (eigendomstheorie); en

3. de rechthebbende reeds in het kader van het eerste aanbod op de markt een passende vergoeding heeft kunnen ontvangen voor het werk (beloningstheorie). ${ }^{72}$

In zijn noot bij het HP/Digital Revolution-arrest werpt Van Kleeff de interessante theorie op dat in het geval van leveranciers zoals HP, die voor het compenseren van de ontwikkelkosten van de software en het verbruikend apparaat zelf afhan-

71. HR 19 april 2019, ECLI:NL:HR:2019:650, IER 2019/21 m.nt. R. van Kleeff (HP/Digital Revolution).

72. Zie uitgebreid over deze verschillende theorieën en hun achtergrond en inhoud M.R.F. Senftleben, Het eerste schaap over de dam. Over het UsedSoft/Oracle-arrest van het HvJ EU en de verdere ontwikkeling van de uitputtingsleer in de digitale omgeving, Auteurs-, Media- \& Informatierecht 2013, afl. 2, p. 56-60, C. Sganga, A Plea for Digital Exhaustion in EU Copyright Law, Journal of Intellectual Property, Information Technology and E-Commerce Law (9) 2019, afl. 3, www.jipitec.eu/ issues/jipitec-9-3-2018/4802; A. Wiebe, The Economic Perspective: Exhaustion in the Digital Age, in: L. Bently, U. Suthersanen \& P. Torremans (red.), Global Copyright, Cheltenham: Edward Elgar Publishing 2010, p. 136-196, https://doi.org/10.4337/9781849806428.00033. 
kelijk zijn van de verkoop van geautoriseerde consumables, het wel mogelijk zou moeten zijn om aan de uitputtingsregel te ontsnappen. Omdat zij volgens Van Kleef niet de mogelijkheid heeft om bij eerste verkoop een passende vergoeding te kunnen verkrijgen, zou zij daarom wel ten aanzien van het gebruik van het soort printercartridges beperkingen moeten kunnen stellen. Dit gebruiksrecht zou dan niet worden omgevormd naar een verkoop in de zin van (de implementatiewetgeving ten aanzien van) de Softwarerichtlijn, en dus ook niet leiden tot uitputting. ${ }^{73}$

Een interessante gedachte, volledig gestoeld op de beloningstheorie, die een van de fundamenten van de uitputtingsleer vormt. Ik kan deze redenering echter niet volgen voor uitputting ten aanzien van embedded software. ${ }^{74}$ Het is namelijk de keuze van de auteursrechthebbende (hier tevens producent) om de eerste verkoopprijs van het product te bepalen. Dat zij er zelf voor kiest om de kosten zo laag te houden om daarmee consumenten binnen te hengelen met relatief lage instapkosten, om vervolgens via de consumablesmarkt dit verlies terug te verdienen, komt wat mij betreft geheel voor haar eigen rekening. Het zou mijns inziens niet zo moeten zijn dat de uitputtingsleer kan worden omzeild door het product voor een (te) lage verkoopprijs in de markt te zetten. Dit zou de twee andere fundamenten van de uitputtingsleer, de vrije verhandelbaarheid en de eigendomstheorie, ook veel tekortdoen.

Het lijkt er dus ook op dat de rol van het auteursrecht bij het behouden van de controle over de consumablesmarkt via de software in het verbruikend apparaat bescheiden is, gelet op de uitputtingsleer.

\subsection{Tussenconclusie}

Resumerend kunnen we dus stellen dat de controle behouden over de consumablesmarkt op basis van de intellectuele-eigendomsrechten ten aanzien van de consumables of verbruikende apparatuur relatief beperkt is. De meeste kans lijkt, bij gebrek aan octrooiconclusies specifiek ten aanzien van de consumable zelf, de weg van de indirecte inbreuk te zijn. Door beperkingen te stellen aan het gebruik van het verbruikend apparaat door middel van algemene voorwaarden kan mogelijk een vordering op basis van indirecte (octrooi-)inbreuk worden onderbouwd. Deze voorwaarden zijn dan niet gericht op de daadwerkelijke gebruiker van het verbruikend apparaat, maar op de concurrerende aanbieders van consumables. Daarbij, zelfs al zou je het exclusieve gebruik van enkel geautoriseerde consumables bij de

73. HR 19 april 2019, ECLI:NL:HR:2019:650, IER 2019/21 m.nt. R. van Kleeff (HP/Digital Revolution).

74. Ik heb meer sympathie voor dit argument in relatie tot software niet vervat in een fysieke drager, hoewel dat zijn eigen problemen met zich meebrengt, zie bijv. de zaak momenteel voor het $\mathrm{HvJ}$ EU inzake eBooks en uitputting en A-G Szpunar bij HvJ EU 10 september 2019, C-263/18, ECLI:EU:C:2019:697 (Nederlands Uitgeversbond/Tom Kabinet). gebruiker juridisch kunnen afdwingen, ${ }^{75}$ hoe ga je dat praktisch handhaven?

\section{Controle over consumables 2.0}

De mogelijkheden om controle te behouden door middel van het juridisch handhaven van het gebruik van de eigen consumables vereist een (zeer) actieve houding van de producent, en is praktisch tijdrovend en duur als het gaat om handhaving van de rechten jegens gebruikers in plaats van concurrenten. Echter, door slim gebruik van technologie kan de handhaving van de rechten van de leverancier aanzienlijk gemakkelijker worden gemaakt.

\subsection{Het verbruikend apparaat als handhaver van (IE-)rechten}

Wanneer het verbruikend apparaat enkel de door de producent geautoriseerde consumables accepteert, is er geen mogelijkheid om concurrerende consumables te gebruiken. Dit is in het verleden al geprobeerd door middel van 'slimme chips' in printers en printercartridges in te bouwen om de werking van de printers te beperken tot cartridges afkomstig van de producent zelf. Tot op zekere hoogte werken deze maatregelen, alleen duiken op het internet al gauw handleidingen op om deze technische maatregelen te omzeilen. Er is voor de producent ook weinig zicht op in hoeverre deze technische maatregelen worden omzeild in de praktijk, wat wederom de handhaving (indien het omzeilen gepaard gaat met een inbreuk op een van de rechten van de producent) ingewikkeld maakt.

Het internet, of specifieker een internetverbinding, kan echter ook de producent helpen bij het behouden van controle over het gebruik van het verbruikend apparaat en de consumables daarin. Zo zijn er meerdere printerfabrikanten die printers aanbieden die op het internet moeten worden aangesloten om te werken, of om een bepaalde functionaliteit aan te bieden - onder het mom van gemak voor de gebruiker; dit gaat vaak samen met het aanbieden van de consumables in abonnementsvorm. ${ }^{76}$

Een grote aantrekkingskracht voor consumenten om consumables in abonnementsvorm af te nemen is het gemak dat daarmee gepaard gaat. De consument hoeft nooit meer te wachten tot de supermarkt opengaat om gauw wat capsules te halen zodat het eerste bakje koffie op de zondagochtend kan worden genuttigd, of de PostNL-app in de gaten houden om te zien wanneer de printercartridge wordt bezorgd. Voor producenten is het aanbieden van consumables in abonnementsvorm eveneens aantrekkelijk, omdat dit een mate van zeker-

75. Hierbij is niet aan de orde gekomen in hoeverre dergelijke bepalingen mededingingsrechtelijke gevolgen kunnen hebben en in hoeverre deze indruisen tegen (EU-)regelgeving ten aanzien van het stimuleren van recyclen van materiaal.

76. Zie ING-rapport 'Now That We Subscribe to Music, Are Tools and Toiletries Next? Opportunities and Challenges for Tangible Goods Subscriptions', april 2018, te vinden via www.ing.nl/media/ ING_EBZ_opportunities-and-challenges-for-tangible-goodssubscriptions_tcm162-143372.pdf. 
heid omtrent afnamefrequentie met zich meebrengt. Daarnaast levert het ook een hoop interessante gebruiksgegevens op, die kunnen worden gebruikt om diensten en producten te verbeteren, maar ook voor reclamedoeleinden. Een nadeel tot nu toe is echter dat de afstemming over daadwerkelijk gebruik, voorraad en wanneer weer een nieuwe (set) consumable(s) moet worden geleverd relatief onnauwkeurig is. Daarnaast kan een concurrent ook een dergelijk abonnement aanbieden. Vandaar de aansluiting van het verbruikend apparaat op het internet. Deze aansluiting biedt namelijk de functionaliteit dat de printer geheel zelfstandig bestellingen gaat doen van (natuurlijk alleen originele) inktcartridges op basis van daadwerkelijk gebruik. ${ }^{77}$ Zo zit je nooit meer zonder inkt of met een kast vol ongebruikte cartridges. ${ }^{78}$

\subsection{Consumables-as-a-Service (CaaS)}

De daaropvolgende stap is ook al genomen: door consumables niet meer aan te bieden in de verkoop, maar als service. Zo neemt men bij deelname aan het HP Instant Ink-programma geen printercartridges meer af, maar de service 'printen'. ${ }^{79}$ Dit past in de bredere trend van de 'servitization' van goederen. ${ }^{80}$ HP Instant Ink lijkt heel erg op een maandelijkse belbundel, maar in plaats van belminuten krijgt de consument iedere maand een nieuwe bundel geprint papier. ${ }^{81}$

Er is zelfs een gratis variant voor 15 velletjes per maand. Print je - zoals je wordt aangeraden - de algemene voorwaarden van het HP Instant Ink-programma à 14 pagina's uit ${ }^{82}$ en daarnaast ook nog dit artikel, dan ga je over je maandelijkse limiet heen. ${ }^{83}$ Je printer print overigens wel gewoon het artikel uit, maar je betaalt voor een set van 10 pagina's $€ 1$ extra. Print je standaard meer dan 15 pagina's per maand, dan zijn er andere abonnementsvormen beschikbaar. Het verbruiksoverzicht van

77. Zie bijv. www.epson.nl/for-home/hassle-free-printing-solutions/ readyink. Overigens zou het via het openstellen van de software via een API bijv. prima mogelijk moeten zijn dat dit soort services ook door andere partijen worden aangeboden. Het ligt alleen niet voor de hand dat een producent van een verbruikend apparaat, indien deze afhankelijk is van de inkomsten uit de consumablesmarkt, de software op het verbruikend apparaat vrijwillig open zal stellen.

78. Men kan zich wel afvragen in hoeverre deze controle wat betreft de particulier wenselijk is, bijv. vanuit het oogpunt van de bescherming van persoonsgegevens.

79. Wel is de aanschaf van een printer nog vereist, maar ook kan worden gedacht aan het leasen van de printer.

80. Hierover is al veel geschreven, een recent overzicht van de verschillende juridische (on)mogelijkheden met betrekking tot dit fenomeen en in het bijzonder de relatie tot het consumentenrecht is te vinden in: V. Mak, Consumentenbescherming bij servitisation, Preadvies Vereniging voor de vergelijkende studie van het recht van België en Nederland 2019, Den Haag, Boom juridisch 2019.

81. Overigens moet het papier nog wel zelf worden aangeschaft. Het is nog niet HP Instant Paper.

82. 'JE KUNT DEZE VOORWAARDEN GEHEEL OF GEDEELTELIJK DOORLEZEN, OPSLAAN OF PRINTEN. WE RADEN JE AAN EEN KOPIE VAN HET HELE DOCUMENT TE PRINTEN EN BIJ DE HAND TE HOUDEN WANNEER JE DE INSTANT INK SERVICE GEBRUIKT.' Zie https://perma.cc/6RZU-JL64.

83. Dubbelzijdig maakt niet uit, het is per zijde, niet per velletje. Daarnaast is voor deze rekensom uitgegaan van 1 pagina per zijde. Dat kan natuurlijk duurzamer. die maand kun je online bekijken, maar is niet te zien op de printer zelf, noch krijg je een seintje als je er (bijna) overheen gaat. $^{84}$

Ook hier treedt het verbruikend apparaat weer op als de handhaver van de (diensten)overeenkomst. De printer werkt alleen als een HP Instant Ink (ready)-cartridge in de printer is opgenomen en verbinding met het internet heeft. ${ }^{85}$ Probeert men toch een concurrerende consumable te gebruiken tijdens de looptijd van het Instant Ink-programma, dan is dat een overtreding van de algemene voorwaarden en een grond voor directe opzegging en het op afstand laten blokkeren van de printer (tot het einde van de maand). In het ergste geval kun je dan dus 30 dagen geen gebruik maken van de printer. ${ }^{86} \mathrm{Na}$ verloop van de resterende abonnementstermijn kan de (nietgeautoriseerde) concurrerende cartridge overigens wel gewoon worden gebruikt. Op deze manier wordt pacta sunt servanda door technologie afgedwongen ${ }^{87}$ en aan de controle over het gebruik van consumables in verbruikende apparatuur tanden gegeven.

\section{Conclusie}

Controle over consumables met behulp van technologische middelen zou de focus kunnen verleggen van handhaving van exclusieve rechten jegens de concurrent naar de rechten uit overeenkomst jegens de consument. Of de technologie zich ook zo verder zal ontwikkelen, is koffiedik kijken, maar als dat gebeurt, is het de vraag of dit geen onwenselijke gevolgen heeft.

Het is namelijk niet voor niets dat er maar beperkte mogelijkheden zijn om uit hoofde van de intellectuele-eigendomsrechten op te kunnen treden jegens aanbieders van concurrerende consumables en de consumenten van verbruikende apparatuur en consumables. Echter, door overeenkomsten die de

84. In een oudere versie van het programma stond nog de volgende voorwaarde voor het gratis programma: 'Als u zich aanmeldt voor marketingberichten, kunt $\mathrm{u}$ het volgende ontvangen bij het 15-gratis-programma: (...) Advertenties, aanbiedingen en promoties van HP, partners van HP en derden ("Advertenties") worden afgedrukt via de Geregistreerde printer met een frequentie van één (1) Advertentie per vijf (5) afgedrukte pagina's. Genoemde Advertenties worden afgedrukt in aanvulling op, tellen niet mee voor en worden niet afgetrokken van de vijftien (15) gratis pagina's die de Deelnemer mag afdrukken via een Geregistreerde printer in het kader van het 15-gratis-programma; en Deelnemers wordt ook niets in rekening gebracht voor eventuele afgedrukte pagina's met Advertenties.' Zie https://web.archive.org/web/20190113170944/https:// instantink.hpconnected.com/nl/nl/terms. Na klachten bij en navraag door de Consumentenbond is deze bepaling geschrapt.

85. Zo lezen we in art. 5 onder c van de Instant Ink-voorwaarden: '(...) Als Uw printer niet is aangesloten op het Internet, dan worden de Instant Ink-geactiveerde Cartridges uitgeschakeld en zult $U$ niet in staat zijn om deze te gebruiken om af te drukken; echter zullen de kosten voor de Service desondanks doorlopend in rekening gebracht worden, zoals beschreven in Paragraaf 7 ("Betalen voor je instant ink service"). (...)'

86. Over de goederenrechtelijke implicaties van dit soort beperkingen heb ik eerder in MvV geschreven. Zie Berlee 2018, p. 255.

87. Zie over dergelijke vormen van 'technoregulering' J.E.J. Prins, Normering, regulering en rechtshandhaving door technologie. Over de implicaties van technoregulering voor het privaatrecht, WPNR 2011/6912, p. 1075-1085. Zie ook Berlee 2018, p. 255. 


\section{Maandblad} Vermogensrecht

consument beperken in zijn keuze voor bepaalde consumables door middel van technologie afdwingbaar te maken, kan de producent met een omweg de keuzevrijheid van de consument beperken en controle over de markt van consumables vergroten, en zo alsnog dus (mogelijk) het stelsel van onvervalste mededinging onder druk zetten.

Het is dan aan algemeen verbintenisrechtelijke leerstukken, zoals de redelijkheid en billijkheid, en consumentrechtelijke bepalingen met betrekking tot de (ver)nietig(baar)heid van onredelijk bezwarende bedingen in algemene voorwaarden om ervoor te zorgen dat het evenwicht tussen de belangen van producent en consument bewaard blijft. De concurrent zal dan afhankelijk zijn van de bepalingen ten aanzien van oneerlijke handelspraktijken en de handhaving van het mededingingsrecht als de producent een economische machtspositie heeft. 